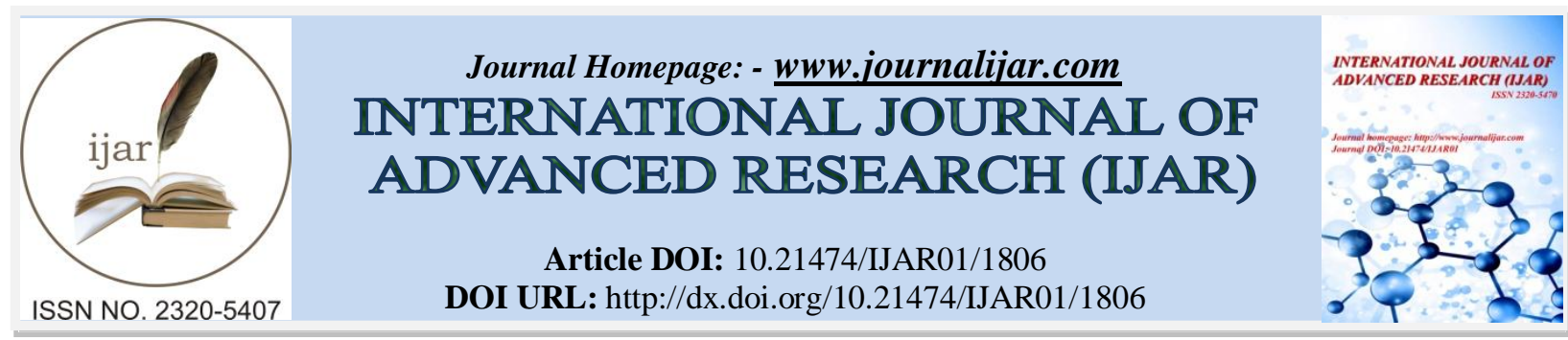

RESEARCH ARTICLE

\title{
CATALYTICAL AND ANTICANCER STUDIES OF COMPLEXES OF 2-[(5-METHOXY-1H- BENZIMIDAZOL-2-YL)SULFONYL]-N-PHENYLACETAMIDE WITH ALKALINE EARTH METAL IONS.
}

\author{
Manish M. Swami ${ }^{1}$, Dr. Haresh R. Patel ${ }^{2}$ and Jabali J. Vora ${ }^{3}$. \\ 1. Sheth shree H.K.Akoliya, Vivekanand Vidyalaya.Dhanera (N.G.) India. \\ 2. Department of Chemistry, Sankalchand Patel University, Visnagar, India. \\ 3. Department of Chemistry, Hemchandracharya North Gujarat University, Patan. India.
}

\section{Manuscript Info}

Manuscript History

Received: 12 August 2016

Final Accepted: 22 September 2016

Published: October 2016

Key words:-

Alkaline earth metal complexes, 2-[(5-

Methoxy-1H-Benzimidazol-2-yl)

Sulfonyl]-N- Phenylacetamide (MBSPA),

Antimicrobial Activity, Anticancer

Activity, catalysis

\section{Abstract}

Many important biochemical compounds and drugs of natural origin contain heterocyclic ring structures. Among carbohydrates, essential amino acids, vitamins, alkaloids, glycosides etc. the presence of heterocyclic structures in such diverse types of compounds strongly indicates that these compounds possess different types of the pharmacological activity. The present work has been done in the search of some potential biochemically active derivatives of 2mercaptobenzothiazole for medicinal as well as nutritional purposes. Currently used compounds which upon substitution at either functional group or linked with heterocyclic rings or molecules with metal ions, many times, capable of performing better. Synthesis of newer molecules is usually carried out by new linkage through functional groups present in molecules. After the synthetic procedure, the newer molecules require spectroscopic characterization in order to ascertain their structure. In the present work ,2-mercapto 5- methoxy benzimidazolmolecule has been linked with $\mathrm{N}$-(4-acetylphenyl)-2chloroacetamide heterocycles and instrumental methods like C,H,N,S Analyzer , FT IR spectroscopy, MASS spectrometry, UV spectroscopy etc. have been used for structure elucidation and their important biological activities and also catalytic properties have been studied.

Copy Right, IJAR, 2016,. All rights reserved.

\section{Introduction:-}

The compound 2-[(5-methyl-1H-Benzemidezole-2-yl)sulfonyle]-N- phenyl Acetamide (MBSPA) is the important intermediate required for the synthesis of omeprazole. The reactions were also performed in the presence of phasetransfer catalysts.

\section{Experimental:-}

Aniline, toluene, TEA (tri ethylamine), dichloromethane, acetone (all analytical grade )and 2-mercapto-5-methoxy1H-benzimidazole were used for the preparation of ligand. $\mathrm{Mg}$ (II), $\mathrm{Ca}$ (II), $\mathrm{Sr}$ (II) and $\mathrm{Ba}$ (II) perchlorates in DMSO were prepared. The exact strength of $0.2 \mathrm{M}$ perchloric acid was determined by $\mathrm{pH}$ metric titration against $0.2 \mathrm{M}$ $\mathrm{NaOH}$ solution (standardized with $0.2 \mathrm{~N}$ oxalic acid). Metal perchlorates were prepared by mixing solid carbonates 
with perchloric acid solution. To a well stirred solution of 4-methoxy aniline (a) ( $0.01 \mathrm{~mol}$. 1.23gm) in dichloromethane $(0.11 \mathrm{~mol} .9 .34 \mathrm{gm})$ acetic anhydride $(0.01 \mathrm{~mol} .1 .02 \mathrm{gm})$ was added drop wise at room temperature in a period of 30 minutes. Organic layer containing N-(4-methoxyphenyl) acetamide (b) $(0.01 \mathrm{~mol})$ was taken in a round bottom flask and cooled to $20-250 \mathrm{C}$. To this solution, concentrated sulphuric acid $(0.015 \mathrm{~mol}, 0.8 \mathrm{ml})$ was added followed by the addition of fuming nitric acid $(0.02 \mathrm{~mol}, 0.88 \mathrm{ml})$ at $20-25^{\circ} \mathrm{c}$ in a period of 2 hours. Organic layer was neutralized by $10 \% \mathrm{NaOH}$ solution. Methanol $(8 \mathrm{ml})$ was added to crude 4-methoxy-2-nitrophenyl) amide $(0.009 \mathrm{~mol})$ and the resulting yellow solution was stirred. $\mathrm{NaOH}(0.027 \mathrm{~mol}, .1 .08 \mathrm{gm})$ was slowly added to it and refluxed at $80{ }^{\circ} \mathrm{C}$. Reaction mass was then stirred at room temperature for another $3 \mathrm{hrs}$. Organic layer containing 4methoxybenzene -1,2-diamide $(0.008 \mathrm{~mol})$ was reduced by adding $\mathrm{Na}_{2} \mathrm{~S} 9 \mathrm{H}_{2} \mathrm{O}(0.016 \mathrm{~mol}, .84 \mathrm{gm})$ and $\mathrm{NaHCO}_{3}$ $(0.014 \mathrm{~mol}, 1.18 \mathrm{gm})$ and water $(6 \mathrm{ml})$. The reaction mixture was refluxed for 5 hours at $80{ }^{\circ} \mathrm{C}$. Organic layer containing 2-mercapto-5-methoxy-1H- Benzimidazole (1.0gm, $0.0072 \mathrm{~mole})$ was cooled at $30{ }^{\circ} \mathrm{C}$. To this, $\mathrm{NaOH}$ $(1.08 \mathrm{gm}, 0.027 \mathrm{~mole})$ was added and stirred at room temperature. $\mathrm{CS}_{2}(1.21 \mathrm{gm}, 0.016 \mathrm{~mole})$ was added slowly in 1 hrs. at temperature below $30^{\circ} \mathrm{C}$. Reaction mass was very carefully heated to reflux for 6 hours. Solvent was evaporated under reduced pressure and reaction mass was acidified to $\mathrm{pH}=2$ by adding $33 \%$ hydrochloric acid 4.0gm, $0.036 \mathrm{~mole}$ ). Yield: $72 \%, 254-255{ }^{\circ} \mathrm{C}$. The organic compound was synthesized out of $11 \mathrm{ml}$ aniline by drop wise addition of $300 \mathrm{ml}$ of the dichloromethane and $25 \mathrm{gm}$ of the potassium carbonate was added then after. Drop wise addition of $25 \mathrm{ml}$ of chloracetyl chloride was followed. The precipitates obtained were filtered. This product A (2-chloro- $N$-phenylacetamide) $(25 \mathrm{gm})$ was dissolved in $300 \mathrm{ml}$ acetone and the compound - B (2-mercapto-5methoxy-1H-benzimidazole) $(18.78 \mathrm{gm})$ was mixed with it and this mixture was stirred well with $25 \mathrm{gm} \mathrm{K}_{2} \mathrm{CO}_{3}$ in ice bath. The light white solid [compound C] (2-[(5-methyl-1H-Benzemidezole-2-yl) sulfonyle]-N- phenyl Acetamide) was obtained by addition of cold water and purified to give the ligand MBSPA. The formation of complexes was carried out by mixing $50 \mathrm{ml} 0.2 \mathrm{M}$ metal perchlorate solution and $50 \mathrm{ml} 0.2 \mathrm{M}$ ligand in DMSO solution. The reaction mixture was refluxed for 2.5 to 3.0 hours at $95{ }^{\circ} \mathrm{C}$ temperature. The $\mathrm{pH}$ of the above solution was then raised up to 6.5 using with aqueous which resulted in the precipitation of the complex.

\section{Analyses and physical measurements:-}

M.P. and TLC were taken with usual apparatus [solvent system for TLC 70\% toluene $+30 \%$ methanol]. Elemental analyses were performed with a Vario-MICRO CUBE C, H, N, S analyzer. The metal content was determined by titration with a solution of standardized disodium salt of EDTA [1].Magnetic susceptibilities were measured by the Gouy's method [2], at room temperature using $\mathrm{Hg}\left[\mathrm{Co}(\mathrm{CNS})_{4}\right]$ as calibrant. The IR spectra were recorded on a BRUKER ALPHA FT-IR $400-4000 \mathrm{~cm}^{-1}$ spectrophotometer. The UV - visible spectra were measured on a UV1800 Shimadzu (Double beam) spectrophotometer. Thermal measurements were performed using a METTLER TOLEDO STARe system TGA/DSC1(11500C) thermal analyzer. The mass spectra analyses were performed with a model QDA of Waters and Alliance 2690 analyzer.

Table 1:- Analytical Data and Some Physical Properties of the Ligand and Metal Complexes.

\begin{tabular}{|c|c|c|c|c|c|c|c|c|c|c|}
\hline $\begin{array}{c}\text { Metal } \\
\text { complex }\end{array}$ & $\begin{array}{c}\text { Molar } \\
\text { Conductions } \\
\text { In DMSO } \\
\text { Mili Mhos } \\
\mathbf{c m}^{-1}\end{array}$ & $\begin{array}{c}\text { Rf } \\
\text { Value }\end{array}$ & Color & $\begin{array}{c}\text { \% of } \\
\text { Yield }\end{array}$ & $\begin{array}{c}\text { \% of } \\
\text { Metal } \\
\text { Exp. } \\
\text { (calc.) }\end{array}$ & $\begin{array}{c}\text { M.P. } \\
\text { 0C }\end{array}$ & $\begin{array}{c}\text { \% of } \\
\mathbf{C} \\
\text { Exp. } \\
\text { (calc.) }\end{array}$ & $\begin{array}{c}\text { \% of } \\
\mathbf{H} \\
\text { Exp. } \\
\text { (calc.) }\end{array}$ & $\begin{array}{c}\text { \% of } \\
\mathbf{N} \\
\text { Exp. } \\
\text { (calc. })\end{array}$ & $\begin{array}{c}\text { \% of S } \\
\text { Exp. } \\
\text { (calc.) }\end{array}$ \\
\hline MBSPA & -- & 0.368 & $\begin{array}{c}\text { Cramy } \\
\text { white }\end{array}$ & -- & -- & 173 & -- & -- & -- & -- \\
\hline $\begin{array}{c}\text { Mg- } \\
\text { MBSPA }\end{array}$ & 11.2 & 0.34 & $\begin{array}{c}\text { Light } \\
\text { Brown }\end{array}$ & $85 \%$ & $\begin{array}{c}4.86 \\
(4.86)\end{array}$ & 160 & $\begin{array}{c}55.97 \\
(60.45)\end{array}$ & $\begin{array}{c}4.95 \\
(4.888)\end{array}$ & $\begin{array}{c}12.24 \\
(12.88)\end{array}$ & $\begin{array}{c}9.32) \\
(28.269)\end{array}$ \\
\hline $\begin{array}{c}\text { Ca- } \\
\text { MBSPA }\end{array}$ & 12.0 & 0.33 & Orange & $83 \%$ & $\begin{array}{c}4.86 \\
(4.86)\end{array}$ & 110 & $\begin{array}{c}51.66 \\
(56.90)\end{array}$ & $\begin{array}{c}5.00 \\
(4.908)\end{array}$ & $\begin{array}{c}11.66 \\
(12.26)\end{array}$ & $\begin{array}{c}8.88 \\
(25.105)\end{array}$ \\
\hline $\begin{array}{c}\text { Sr- } \\
\text { MBSPA }\end{array}$ & 69.3 & 0.32 & $\begin{array}{c}\text { Bright } \\
\text { Brown }\end{array}$ & $93 \%$ & $\begin{array}{c}7.00 \\
(8.9)\end{array}$ & $152-155$ & $\begin{array}{c}51.2 \\
(56.63)\end{array}$ & $\begin{array}{c}4.53 \\
(4.474)\end{array}$ & $\begin{array}{c}11.2 \\
(11.02)\end{array}$ & $\begin{array}{c}8.53 \\
(24.114)\end{array}$ \\
\hline $\begin{array}{c}\text { Ba- } \\
\text { MBSPA }\end{array}$ & 10.5 & 0.35 & $\begin{array}{c}\text { Dark } \\
\text { Bright } \\
\text { Brown }\end{array}$ & $82 \%$ & $\begin{array}{c}5.49 \\
(9.79)\end{array}$ & 150 & $\begin{array}{c}45.98 \\
(57.21)\end{array}$ & $\begin{array}{c}4.55 \\
(4.846)\end{array}$ & $\begin{array}{c}10.05 \\
(11.81)\end{array}$ & $\begin{array}{c}7.66 \\
(26.986)\end{array}$ \\
\hline
\end{tabular}

EDTA titration method, Exp. $=$ experimental. 


\section{Physico chemical properties:-}

Molar conductances of complexes indicate nonionic nature. Rf and melting point values suggest complexes formation. Elemental analyses support the molecular formula that is thought of. However, percentages of sulfur do not agree with the experimental values probably because of some instrumental disturbances.

\section{IR Spectra:-}

Infrared spectroscopic technique [3-6] is of an immense importance to organic chemists for the identification of the presence of functional groups as well as carbon skeleton in the organic compounds.

IR (KBr): 3282(N-H Stre.), 1600 (>C=O stre.), 1444 (-C=N stre.), 1075,1114 (Ar-C-H aromatic), 1330-1444 (-CH - $_{2}$ stre.), 751,750,759,756 (C-S stre., $\mathrm{M}=\mathrm{Mg}^{2+}$ ), 417 (M-S stre., $\mathrm{M}=\mathrm{Ca}^{2+}, \mathrm{Sr}^{2+} . \mathrm{Ba}^{2+}$ ), 478,462,472 (M-O stre.), 673,691,692 (M-N stre.), and 673 (o-di substituted benzene stre.). 1454- $\left(\mathrm{CH}_{2}\right)$ Scissoring, 1395- wagging and twisting, 1114 (-C-O-C stre.)- Asymmetric stretching, $1648(-\mathrm{N}-\mathrm{H})$ in plane bending. All the figures in $\mathrm{cm}^{-1}$.

\section{Mass spectrometry:-}

Probably the most common uses of mass spectrometry by the chemist is for the accurate determination of molecular weight as well as structure elucidation.

Mg-MBSPA :- Mass m/z:- Base peak $=314.1 \mathrm{amu},($ B. P. +1$)$ is around $13 \%$ of B.P. (314.1) therefore 12 carbon atoms present in the fragment corresponding to base peak and Base peak +2 presence of $=$ confirms presence of sulphur, Thus base peak is due to ligand molecule MBSPA, Base peak+ metal $=337.67 \mathrm{amu}$, Base peak - Aniline $=221.1 \mathrm{amu}$, Base peak + Metal $=336.2 \mathrm{amu}$

Ca-MBSPA:- Mass m/z:- Base peak $=314.1$ amu ,(B. P. +1$)$ is around $15 \%$ of B.P. (314.1) therefore 14 carbon atoms present in the fragment corresponding to base peak,,S is present in base peak $(314+2)$ so base peak is pertaining to ligand, Base peak + Metal $=353.44 \mathrm{amu}$, Base peak - Aniline $=221.1 \mathrm{amu}$

Sr-MBSPA:- Mass m/z:- Base peak $=314.1 \mathrm{amu},($ B. P. +1$)$ is around $12 \%$ of B.P. (314.2) therefore 11 carbon atoms present in the fragment corresponding to base peak, Presence of ' $S$ ' indicated by (base peak +2 ). Thus base peak is due to ligand molecule.,Metal + base peak $=400.99 \mathrm{amu}$, Base peak - Aniline $=221.1 \mathrm{amu}$

Ba-MBSPA:- Mass m/z:- Base peak $=314.1 \mathrm{amu},($ B. P. +1$)$ is around $15 \%$ of B.P. (314.1) therefore 14 carbon atoms present in the fragment corresponding to base peak is due to the ligand molecule. Base peak - Aniline $=221.1$ amu, Metal + base peak $-\mathrm{N}-\mathrm{Ph}=317.7 \mathrm{amu}$.

\section{Magnetic moments:-}

The magnetic moments of the complexes were measured by the Gouy's method. The room temperature magnetic moment of the solid complexes was found to be Diamagnetic. 
Table 2:- Electronic spectra and Magnetic properties

\begin{tabular}{|c|c|c|c|c|c|c|}
\hline \multirow[t]{2}{*}{ N0. } & \multirow[t]{2}{*}{$\begin{array}{c}\text { Brief } \\
\text { name of } \\
\text { complex }\end{array}$} & \multirow[t]{2}{*}{ Formula } & \multirow[t]{2}{*}{$\begin{array}{c}\text { Molecular } \\
\text { weight } \\
\text { Gm/mol }\end{array}$} & $\begin{array}{l}\text { Electronic } \\
\text { Spectra }\end{array}$ & \multirow[t]{2}{*}{$\begin{array}{c}\text { Magnetic } \\
\text { moment } \\
\text { (B.M.) }\end{array}$} & \multirow{2}{*}{$\begin{array}{c}\text { Pascle's } \\
\text { Diamagnetic } \\
\text { correction } \\
\text { erg.G-2mol- } \\
1\end{array}$} \\
\hline & & & & $\mathrm{Nm} \quad \rightarrow \mathrm{cm}-1$ & & \\
\hline 1. & $\begin{array}{c}\mathrm{Mg}- \\
\text { MBSPA }\end{array}$ & {$\left[\mathrm{Mg}\left(\mathrm{C}_{16} \mathrm{H}_{15} \mathrm{O}_{2} \mathrm{~N}_{3} \mathrm{~S}\right)_{2}\left(\mathrm{H}_{2} \mathrm{O}\right)_{2}\right]$} & 86 & $\begin{array}{l}300.50 \rightarrow 33277 \\
253.50 \rightarrow 39447 \\
241.50 \rightarrow 41407 \\
231.50 \rightarrow 43196 \\
228.50 \rightarrow 43776 \\
218.50 \rightarrow 45766\end{array}$ & Diamagnetic & $-372.44 \times 10-6$ \\
\hline 2. & $\begin{array}{c}\text { Ca- } \\
\text { MBSPA }\end{array}$ & {$\left[\mathrm{Ca}\left(\mathrm{C}_{16} \mathrm{H}_{15} \mathrm{O}_{2} \mathrm{~N}_{3} \mathrm{~S}\right)_{2}\left(\mathrm{H}_{2} \mathrm{O}\right)_{2}\right] \mathrm{H}_{2} \mathrm{O}$} & 720 & $\begin{array}{l}300.50 \rightarrow 33277 \\
255.00 \rightarrow 39215 \\
231.50 \rightarrow 43196 \\
221.00 \rightarrow 45248\end{array}$ & Diamagnetic & $-388.31 \times 10-6$ \\
\hline 3. & $\begin{array}{c}\text { Sr- } \\
\text { MBSPA }\end{array}$ & {$\left[\mathrm{Sr}\left(\mathrm{C}_{16} \mathrm{H}_{15} \mathrm{O}_{2} \mathrm{~N}_{3} \mathrm{~S}\right)_{2}\left(\mathrm{H}_{2} \mathrm{O}\right)_{2}\right]$} & 750 & $\begin{array}{l}305.50 \rightarrow 32733 \\
255.00 \rightarrow 39215 \\
239.50 \rightarrow 41753 \\
220.00 \rightarrow 45454\end{array}$ & Diamagnetic & $-383.44 \times 10-6$ \\
\hline 4. & $\begin{array}{c}\text { Ba- } \\
\text { MBSPA }\end{array}$ & {$\left[\mathrm{Ba}\left(\mathrm{C}_{16} \mathrm{H}_{15} \mathrm{O}_{2} \mathrm{~N}_{3} \mathrm{~S}\right)_{2}\left(\mathrm{H}_{2} \mathrm{O}\right)_{3}\right] \mathrm{H}_{2} \mathrm{O}$} & 835 & $\begin{array}{l}302.00 \rightarrow 33112 \\
256.00 \rightarrow 39062 \\
244.50 \rightarrow 40899 \\
228.00 \rightarrow 43859 \\
221.00 \rightarrow 45248 \\
209.00 \rightarrow 47846\end{array}$ & Diamagnetic & $-314.1 \times 10-6$ \\
\hline
\end{tabular}

Electronic spectra and Magnetic properties:-

The alkaline earth metals are usually diamagnetic due to absence of unpaired electrons. The organic ligand is also diamagnetic. Measurements of magnetic susceptibilities helps to observe any paramagnetism present like TIP or spin- orbit coupling. In all the four cases complexes were found to be diamagnetic. Likewise, due to absence of d-d transitions in alkaline earth metal ion complexes, not much information could be obtained except charge transfer transitions.

\section{Thermo gravimetric analysis:-}

Thermo gravimetric analysis (TGA) can provid about physical phenomena, such as second-order phase transitions, including vaporization, absorption, sublimation, adsorption and desorption. chemical (especially dehydration), decomposition and solid gas reactions (e.g., oxidation or reduction)[7] TGA is commonly used to determine selected characteristics of materials that exhibit either mass loss or gain due to decomposition, oxidation or loss of volatiles (such as moisture).

Differential scanning calorimetry is a technique determining the variation in the heat flow given out or taken in by a sample.

Table 3:- Thermo gravimetric analysis

\begin{tabular}{|c|c|c|c|c|c|c|}
\hline \multirow[t]{2}{*}{ Compound } & \multicolumn{3}{|c|}{ RT $-150^{\circ} \mathrm{C}$} & \multicolumn{3}{|c|}{$150^{\circ} \mathrm{C}-250^{\circ} \mathrm{C}$} \\
\hline & $\begin{array}{c}\% \text { weight } \\
\text { loss }\end{array}$ & $\begin{array}{l}\% \text { Loss of } \\
\text { weight(gm) } \\
\text { for } 1 \text { mole } \\
\text { complex }\end{array}$ & $\begin{array}{c}\text { water } \\
\text { molecules }\end{array}$ & $\%$ weight loss & $\begin{array}{c}\% \text { Loss of } \\
\text { weight(gm) for } \\
\text { l mole complex }\end{array}$ & $\begin{array}{c}\text { water } \\
\text { molecules }\end{array}$ \\
\hline Mg-MBSPA & 4.7 & 4.95 & 0 & 12.83 & 43.25 & 2 \\
\hline Ca-MBSPA & 3.18 & 11.24 & 1 & 9.47 & 33.44 & 2 \\
\hline Sr-MBSPA & 0.80 & 3.24 & 0 & 8.83 & 35.41 & 2 \\
\hline Ba-MBSPA & 3.33 & 15.02 & 1 & 12.36 & 55.63 & 3 \\
\hline
\end{tabular}

RT $=$ Room temperature . 
Based upon the results of physicochemical analyses their probable structures are as shown in figures below.

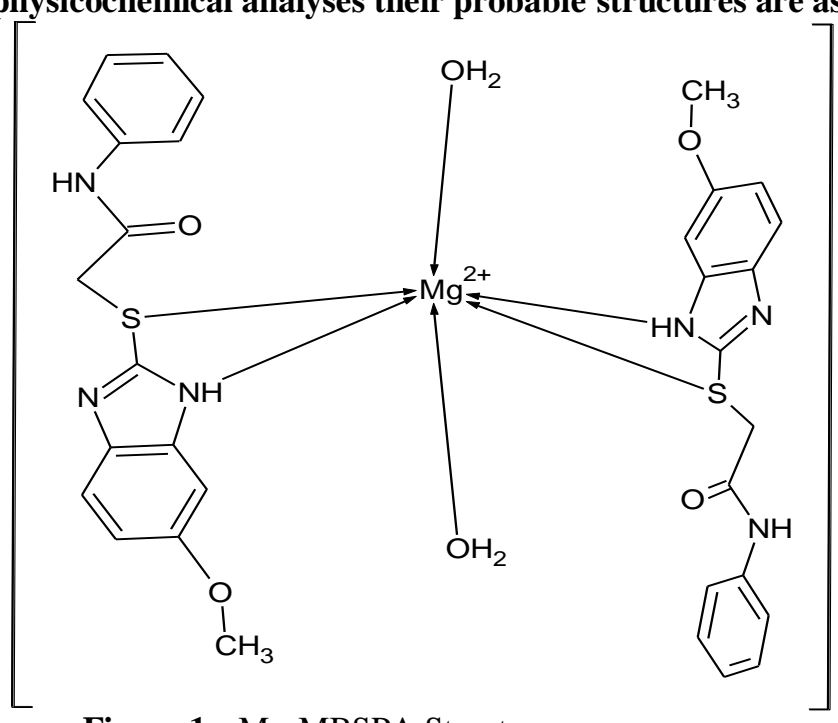

Figure 1:- Mg-MBSPA Structure

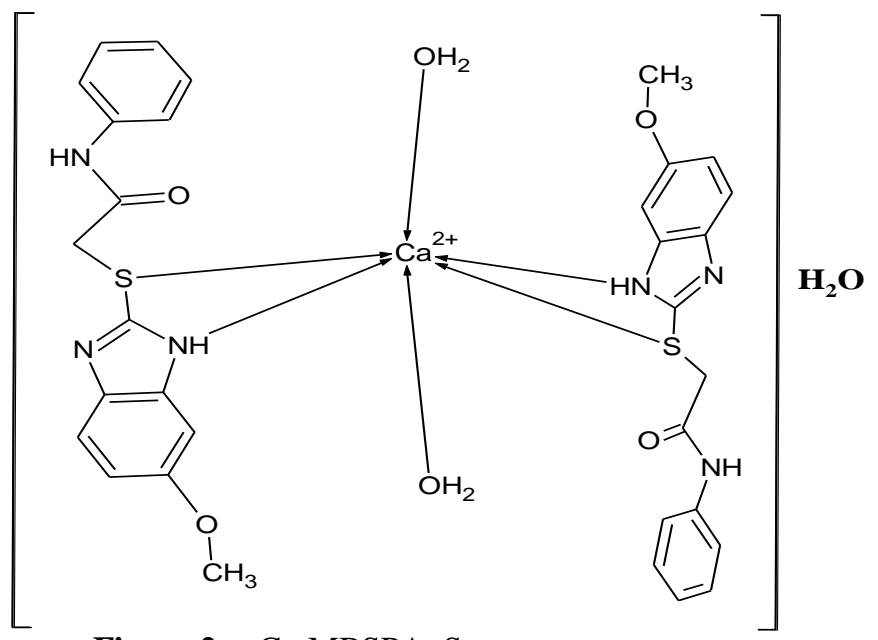

Figure 2:- Ca-MBSPA Structure

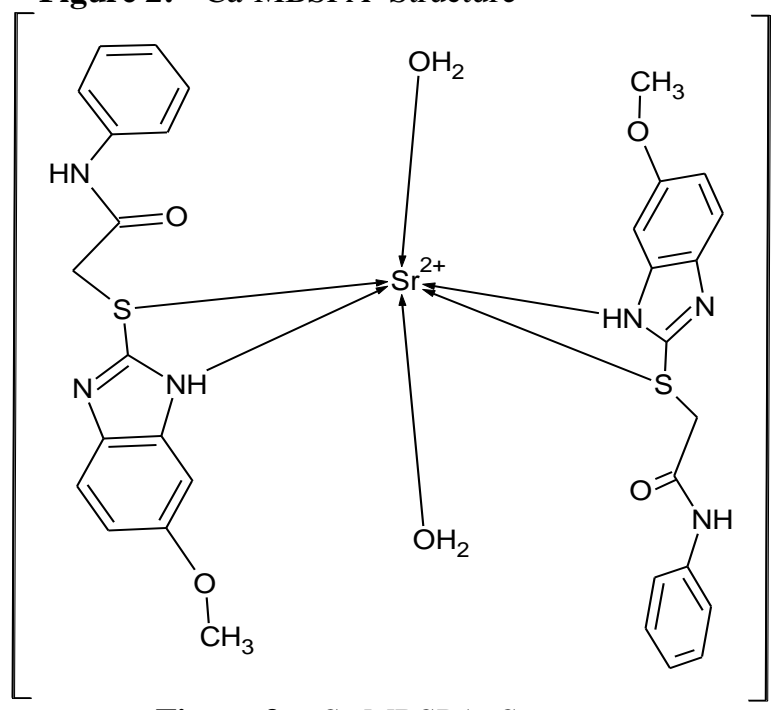

Figure 3:- Sr-MBSPA Structure 


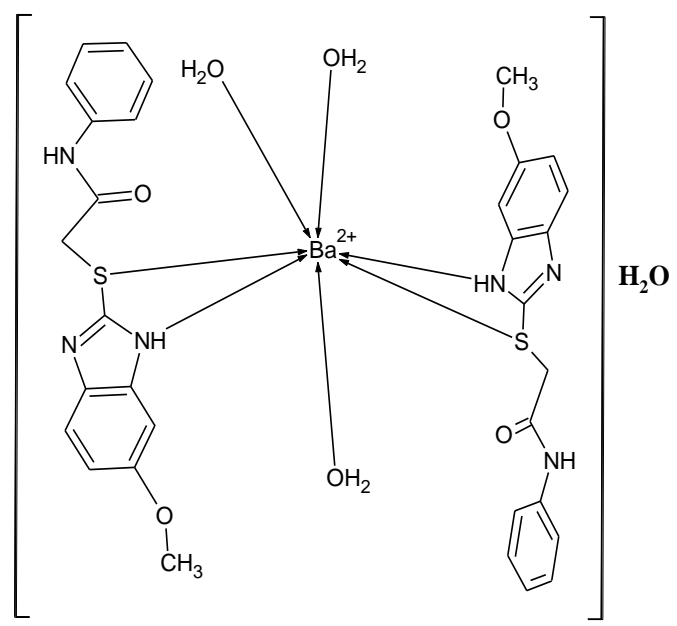

Chemical kinetics:-

Figure 4:- Sr-MBSPA Structure

Three reactions (i) $\mathrm{K}_{2} \mathrm{~S}_{2} \mathrm{O}_{8}+\mathrm{KI}$ (ii) $\mathrm{KBrO}_{3}+\mathrm{KI}$ and (iii) $\mathrm{H}_{2} \mathrm{O}_{2}+\mathrm{KI}$ were selected. These reactions are usually carried out in neutral or acidic medium. The reactions are such that they proceed with moderate velocity $\mathrm{K}=10^{-2}$ to $10^{-5}$ per minute. The product of all these three reactions is iodine which is titrated with standard aqueous sodium thiosulphate. The rates of all these reactions can easily be measured by simple kinetic methods therefore one of the important applications of coordination compounds, as catalysts, is being investigated [8].

\section{Reactions:-}

(i) Reaction-1

$\mathrm{K}_{2} \mathrm{~S}_{2} \mathrm{O}_{8}+2 \mathrm{KI} \longrightarrow 2 \mathrm{~K}_{2} \mathrm{SO}_{4}+\mathrm{I}_{2}$

(ii) Reaction-2

$\mathrm{KBrO}_{3}+\mathrm{HCl} \longrightarrow \mathrm{KCl}+\mathrm{HBrO}_{3}$

(iii) Reaction-3

$\mathrm{H}_{2} \mathrm{O}_{2}+2 \mathrm{HI} \longrightarrow 2 \mathrm{H}_{2} \mathrm{O}+\mathrm{I}_{2}$

Titration of librated iodine for all:

$2 \mathrm{~S}_{2} \mathrm{O}_{3}{ }^{2-}+\mathrm{I}_{2} \longrightarrow 2 \mathrm{I}^{-}+\mathrm{S}_{4} \mathrm{O}_{6}{ }^{2-}$

\section{Catalysis of Organic Reaction:-}

Azoxybenzene is an azo compound, it gives a substitution reaction. Azoxybenzene also gives intra molecular rearrangement in presence of concentrated $\mathrm{H}_{2} \mathrm{SO}_{4}$. It reduces to give azobenzene. It can be prepared by boiling with methanol in alkaline medium. Methanol is oxidized to formic acid while nitrobenzene is converted to Azoxybenzene.

Table 4:- Overall results of catalytic activity for complexes of Alkaline earth metals.

\begin{tabular}{|c|c|c|c|c|c|c|c|c|c|}
\hline Reactions & $\begin{array}{c}\text { k witho } \\
\text { ut } \\
\text { complex }\end{array}$ & $\begin{array}{c}\text { k with } \\
(1 \%) \\
\text { Mg- } \\
\text { MBSP } \\
\text { A }\end{array}$ & $\begin{array}{c}\text { k with } \\
(1 \%) \\
\text { Ca- } \\
\text { MBSP } \\
\text { A }\end{array}$ & $\begin{array}{c}\text { k with } \\
(1 \%) \\
\text { Sr- } \\
\text { MBSP } \\
\text { A }\end{array}$ & $\begin{array}{c}\text { k with } \\
(1 \%) \\
\text { Ba- } \\
\text { MBSP } \\
\text { A }\end{array}$ & $\begin{array}{c}\% \text { Increase } \\
\text { in } \\
\text { reaction rat } \\
\text { e } \\
\text { at } \\
\mathrm{T}=\mathbf{3 0 0} \mathrm{K} \\
\text { for } \\
\text { Mg- } \\
\text { MBSPA }\end{array}$ & $\begin{array}{c}\text { \% Increase } \\
\text { in } \\
\text { reaction rat } \\
\text { e } \\
\text { at } \\
\mathbf{T}=\begin{array}{c}\mathbf{3 0 0} \mathrm{K} \\
\text { for }\end{array} \\
\text { Ca-MBSPA }\end{array}$ & $\begin{array}{c}\text { \% Increase } \\
\text { in } \\
\text { reaction rat } \\
\text { e } \\
\text { at } \\
\mathbf{T}=\mathbf{3 0 0} \mathrm{K} \\
\text { for } \\
\text { Sr-MBSPA }\end{array}$ & $\begin{array}{c}\text { \% Increase } \\
\text { in } \\
\text { reaction rat } \\
\mathrm{e} \\
\text { at } \\
\mathrm{T}=\mathbf{3 0 0} \mathrm{K} \\
\text { for } \\
\text { Ba-MBSPA }\end{array}$ \\
\hline $\begin{array}{c}\mathrm{K}_{2} \mathbf{S}_{2} \mathbf{O}_{8}+ \\
\text { KI }\end{array}$ & $\begin{array}{l}2.085 \\
\times 10^{-5}\end{array}$ & $\begin{array}{c}9.96 \mathrm{X} \\
10^{-6}\end{array}$ & $\begin{array}{c}7.44 X \\
10^{-6}\end{array}$ & $\begin{array}{c}6.91 X \\
10^{-5}\end{array}$ & $\begin{array}{c}9.08 \mathrm{X} \\
10^{-6}\end{array}$ & $-52.23 *$ & $-64.31 *$ & 231.41 & $-56.45 *$ \\
\hline $\begin{array}{c}\mathrm{KBrO}_{3}+ \\
\mathrm{HI}\end{array}$ & $\begin{array}{r}1.44 \\
\times 10^{-3} \\
\end{array}$ & $\begin{array}{c}2.12 X \\
10^{-3}\end{array}$ & $\begin{array}{c}1.73 X \\
10^{-3} \\
\end{array}$ & $\begin{array}{c}1.78 X \\
10^{-3} \\
\end{array}$ & $\begin{array}{c}1.78 X \\
10^{-3}\end{array}$ & 47.22 & 20.13 & 23.61 & 23.61 \\
\hline $\mathrm{H}_{2} \mathrm{O}_{2}+\mathrm{HI}$ & $\begin{array}{l}6.78 \\
\times 10^{-5}\end{array}$ & $\begin{array}{c}3.47 \mathrm{X} \\
10^{-4}\end{array}$ & $\begin{array}{c}4.06 X \\
10^{-4}\end{array}$ & $\begin{array}{c}3.52 \mathrm{X} \\
10^{-4}\end{array}$ & $\begin{array}{c}3.44 X \\
10^{-4}\end{array}$ & 411.79 & 498.82 & 419.17 & 407.37 \\
\hline
\end{tabular}

*Decrease in the reaction rate 
4<smiles>O=[N+]([O-])c1ccccc1</smiles>

Nitrobenzene

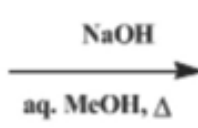

Figure 5:- Reaction of Azoxybenzene

As per the literature, for this reaction, 23gm of sodium hydroxide is added to a solution of $15 \mathrm{ml}$ of nitrobenzene in $120 \mathrm{ml}$ of methanol. After 3 hours refluxing orange coloured solution is observed. Then after methanol is distilled as much as possible. After that the reaction mixture is poured in cold water and mixture is made acidic with $\mathrm{HCl}$. The crude azoxybenzene is separated by the separating funnel. The bottom organic layer is collected which solidifies at around $1^{\circ} \mathrm{C}$ to $2^{\circ} \mathrm{C}$.[9]

Table :- 5 Percentage yield with catalyst alkaline earth metal complex

\begin{tabular}{|c|c|c|c|c|c|c|}
\hline & $\begin{array}{c}\text { Product } \\
\text { Weight } \\
\text { without metal } \\
\text { complex } \\
\text { (3 hours) }\end{array}$ & $\begin{array}{c}\text { Product } \\
\text { Weight } \\
\text { without metal } \\
\text { complex } \\
\mathbf{2} \text { hours }\end{array}$ & $\begin{array}{c}\text { Product } \\
\text { weight using } \\
\text { Mg-BSPA as } \\
\text { catalyst } \\
\mathbf{2} \text { hours }\end{array}$ & $\begin{array}{c}\text { Product weight } \\
\text { using } \\
\text { Ca-MBSPA as } \\
\text { catalyst } \\
\mathbf{2} \text { hours }\end{array}$ & $\begin{array}{c}\text { Product } \\
\text { weight using } \\
\text { Sr -MBSPA } \\
\text { as catalyst } \\
\text { 2 hours }\end{array}$ & $\begin{array}{c}\text { Product } \\
\text { weight using } \\
\text { Ba-MBSPA } \\
\text { as catalyst } \\
\text { 2 hours }\end{array}$ \\
\hline $\begin{array}{c}\text { Weight in } \\
\text { gram }\end{array}$ & 7.93 & 4.95 & 6.10 & 6.20 & 5.90 & 6.25 \\
\hline \% yield & $86.19 \%$ & $60.36 \%$ & $74.39 \%$ & $75.60 \%$ & $71.95 \%$ & $76.21 \%$ \\
\hline
\end{tabular}

(\% yield for $0.05 \%$ catalyst addition)

\section{Result and Discussion:-}

The Azoxybenzene formation reaction is a well known and important reaction. This is usually carried out for a time period of three hours to yield product. When this reaction is carried out for two hours, $60.36 \%$ yield was obtained. On application of $0.05 \%$ of alkaline earth metal ion complex with MBSPA ligand, the rate of reaction increased as a consequence, parentage yield also increased. The catalytic efficiency observed is, Ba-MBSPA > Ca-MBSPA > MgMBSPA > Sr-MBSPA.

\section{Antibacterial activity:-}

This part deals with the in-vitro screening of newly prepared compounds for antibacterial activity. The species S.aureus, E.coli, S.Pyogenes and P.Aeruginosa have been taken for the antibacterial activities. Agar-cup method was employed for the in-vitro screening for antibacterial activity.[10]

Table 6:- Standard drugs.

\begin{tabular}{|c|c|}
\hline Culture & Well No. \\
\hline Bacillus sp. & ++ \\
\hline Staphylococcus aureus & +++ \\
\hline E. coli & +++ \\
\hline Salmonella typhi & +++ \\
\hline
\end{tabular}

Table 7:- Antibacterial activity of MBSPA and alkaline earth metal complexes

\begin{tabular}{|c|c|c|c|c|c|}
\hline & & \multicolumn{4}{|c|}{ Compounds Name } \\
\hline & & Mg-MBSPA & Ca-MBSPA & Sr-MBSPA & Ba-MBSPA \\
\hline Culture & Well No. & & & & \\
\hline \multirow{3}{*}{ Bacillus $s p}$. & $4(100 \mu \mathrm{g} / \mathrm{ml})$ & + & - & - & + \\
\cline { 2 - 6 } & $\mathbf{3}(\mathbf{2 0 0} \boldsymbol{\mu g} / \mathbf{m l})$ & + & + & - & ++ \\
\cline { 2 - 6 } & $\mathbf{2}(300 \mu \mathrm{g} / \mathrm{ml})$ & + & ++ & - & ++ \\
\cline { 2 - 6 } & $1(400 \mu \mathrm{g} / \mathrm{ml})$ & +++ & ++ & - & +++ \\
\hline & & & - & - & - \\
\hline
\end{tabular}




\begin{tabular}{|c|c|c|c|c|c|}
\hline \multirow[t]{3}{*}{ aureus } & $3(200 \mu \mathrm{g} / \mathrm{ml})$ & + & + & - & - \\
\hline & $2(300 \mu \mathrm{g} / \mathrm{ml})$ & + & + & + & + \\
\hline & $1(400 \mu \mathrm{g} / \mathrm{ml})$ & ++ & + & + & + \\
\hline \multirow[t]{4}{*}{ E. coli } & $4(100 \mu \mathrm{g} / \mathrm{ml})$ & - & + & - & - \\
\hline & $3(200 \mu \mathrm{g} / \mathrm{ml})$ & + & + & - & + \\
\hline & $2(300 \mu \mathrm{g} / \mathrm{ml})$ & + & + & + & + \\
\hline & $1(400 \mu \mathrm{g} / \mathrm{ml})$ & ++ & + & + & + \\
\hline \multirow[t]{4}{*}{ Salmonella typhi } & $4(100 \mu \mathrm{g} / \mathrm{ml})$ & - & - & - & - \\
\hline & $3(200 \mu \mathrm{g} / \mathrm{ml})$ & - & + & + & - \\
\hline & $2(300 \mu \mathrm{g} / \mathrm{ml})$ & + & + & + & - \\
\hline & $1(400 \mu \mathrm{g} / \mathrm{ml})$ & ++ & ++ & ++ & + \\
\hline
\end{tabular}

Zone Size:

+++2.6 to $3.0 \mathrm{~cm}$ Streptomycin $(25 \mu \mathrm{g} / \mathrm{disc})$ for $E$. coli, S. typhi \& S. aureus

++ 2.0 to $2.5 \mathrm{~cm}$ Ampicilin $(25 \mu \mathrm{g} / \mathrm{ml})$ for Bacillus sp.

+1.0 to $1.9 \mathrm{~cm}$ Ketoconazole $(\mathbf{1 0} \boldsymbol{\mu \mathrm { g }} / \mathrm{ml})$ for Yeast and Aspergillus

- No zone Well Size is $0.8 \mathrm{~cm}$

Comparison of antimicrobial activity of synthesized compounds with that of standard antimicrobial drugs reveals that the complexes show moderate to good activity against all four bacterial strains, however by and large lower than the standard.

Antifungal activity:-

This part deals with the in-vitro screening of newly prepared complexes for antibacterial activity. The species $C$. albicans,A. niger, A. clavatus have been taken for the antifungal activities. Here too, the Agar-cup method was used for the in-vitro screening for antifungal activity. $[11,12]$

Table 8:- Standard drugs.

\begin{tabular}{|c|c|}
\hline Yeast & + \\
\hline Aspergillus & + \\
\hline
\end{tabular}

Table 9:- Anti fungal activity of MBSPA and alkaline earth metal complexes.

\begin{tabular}{|c|c|c|c|c|c|}
\hline (2) & 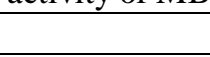 & \multicolumn{4}{|c|}{ Compounds Name } \\
\hline & & Mg-MBSPA & Ca-MBSPA & Sr-MBSPA & Ba-MBSPA \\
\hline Culture & Well No. & & & & \\
\hline \multirow[t]{4}{*}{ Yeast } & $4(100 \mu \mathrm{g} / \mathrm{ml})$ & - & - & - & - \\
\hline & $3(200 \mu \mathrm{g} / \mathrm{ml})$ & - & - & + & - \\
\hline & $2(300 \mu \mathrm{g} / \mathrm{ml})$ & - & - & ++ & - \\
\hline & $1(400 \mu \mathrm{g} / \mathrm{ml})$ & + & - & ++ & + \\
\hline \multirow[t]{4}{*}{ Aspergillus } & $4(100 \mu \mathrm{g} / \mathrm{ml})$ & - & - & - & - \\
\hline & $3(200 \mu \mathrm{g} / \mathrm{ml})$ & - & - & - & - \\
\hline & $2(300 \mu \mathrm{g} / \mathrm{ml})$ & - & + & - & - \\
\hline & $1(400 \mu \mathrm{g} / \mathrm{ml})$ & + & + & + & + \\
\hline
\end{tabular}

+1.0 to $1.9 \mathrm{~cm}$ Ketoconazole $(10 \mu \mathrm{g} / \mathrm{ml})$ for Yeast and Aspergillus

- No zone Well Size is $0.8 \mathrm{~cm}$

Comparison of antimicrobial activity of complexes with that of standard antimicrobial drugs reveals that the synthesized complexes show moderate to good activity against all three fungal strains. 


\section{Anticancer activity:-}

To study cytotoxic activity of a compound, cytotoxic assays are carried out. It is now well-documented that apoptosis or programmed cell death is the key mechanism by which Chemotherapeutic agents exert their cytotoxicity.

\section{Result and Discussion:-}

In the present investigation, all the compounds were evaluated against various cell lines named MDA-MB-468, VERO (Normal Cell) and HCT-15 for each tested compound as well as Std. anticancer drug Methotrexate, Dose Response Curve (DRC) against all cell lines was plotted with 10 analysis point i.e. with 10 different drug concentrations. The concentration causing 50\% cell growth inhibition (IC50) was determined from DRC using GraphPad Prism software (Ver. 5.04) (GraphPad Software, Inc., USA) and Micorsoft Excel 2007 (Microsoft Corporation, USA) application.

Amongst all the tested compounds, for MDA-MB-468 cell line compound Ca-MBSPA (IC 50 value $42.98 \mu \mathrm{g} / \mathrm{ml}$ ) both were giving potent inhibitory effect under studied cell line. While, Ba-MBSPA (IC50 value $91.70 \mu \mathrm{g} / \mathrm{ml}$ ), SrMBSPA (IC50 value $94.08 \mu \mathrm{g} / \mathrm{ml}$ ) gives good effect on said cell line. Similarly for HCT-15 cell line, Ca-MBSPA and Ba-MBSPA were found to be potent against Human colon cancer cell line. Normal cell study was under taken by using VERO cell and study was indicated that Ca-MBSPA was found to be toxic to normal cell. So, one cannot used for further mechanism based study. While rest of compounds can go for further mechanism based study by selecting their potential $\mathrm{IC}_{50}$ values for inhibition. Then after, one can go for further in vivo study of the non-toxic compounds series for detail mechanistic study using Tunnel assay, Flow cytometry, DNA fragmentation assay Or CASPACASE assay.

\section{Conclusion:-}

From above all the results, it can be concluded that compounds Ca-MBSPA and Ba-MBSPA give good cytotoxic activity on MDA-MB-468 cell lines (i.e. Human Breast cancer Cell line). While Ca-MBSPA and Ba-MBSPA compounds show potent activity on HCT-15 cell lines (Human Colon Cancer). When normal cell comparison study was carried out, it was proven by study that compound Ca-MBSPA was toxic to normal cell. All results were compared with standard anticancer drug Methotrexate using IC 50 values for all three cell lines.

\section{Acknowledgments:-}

Authors thank to CIMF (Central Instrument Maintenance Facility) Hemchandracharya North Gujarat University, Patan, India, for analyses.

\section{References:-}

1. Greig, D., Hall, M. J., Hammond, C., Hickey, B. J., Ho, H. P., Howson, M. A., and Wright, D. G. The giant magnetoresistance of $\mathrm{Co} / \mathrm{Cu}$ superlattices grown by MBE. Journal of magnetism and magnetic materials, ,110(3),. p-L239L246 (1992).

2. Liu, W., Cao, F., Chang, L., Zhang, Z., and Zhang, J. Effect of rare earth element Ce and La on corrosion behavior of AM60 magnesium alloy. Corrosion Science, ,51(6), p-1334-1343(2009).

3. Hansch, C., Leo, A., Unger, S. H., Kim, K. H., Nikaitani, D., and Lien, E. J. Aromatic substituent constants for structureactivity correlations. Journal of medicinal chemistry, , 16(11), 1207-1216(1973).

4. Kemp, William. "Infrared spectroscopy." Organic Spectroscopy": p-19-99(1991).

5. Abe, F., Albrow, M. G., Amendolia, S. R., Amidei, D., Antos, J., Anway-Wiese, C.,. and Budd, H. S. Evidence for top quark production in $\mathrm{p}^{-} \mathrm{p}$ collisions at $\sqrt{\mathrm{s}}=1.8 \mathrm{TeV}$. Physical Review D, ,50(5), . p-2966(1994).

6. Bellamy, L. J. The infra-red spectra of complex molecules (Vol. 1,). London: Chapman and Hall., p. 386-388(1975).

7. Coates, J. P. The interpretation of infrared spectra: Published reference sources. Applied spectroscopy reviews, , 31(1-2), p- 179-192(1996).

8. Coats, A. W.; Redfern, J. P. "Thermo gravimetric Analysis: A Review". Analyst 88:. p-906-924(1963).

9. Wilson, James Matchett, R. J. Newcombe, and A. R. Denaro. "Experiments in physical chemistry". Elsevier,(2013). p-15

10. Sobota, P., Płuziński, T., and Rummel, S. "Reaction of nitrobenzene and azobenzene with transition metal compounds in low oxidation state." Tetrahedron, ,37(5), p-939-942(1981).

11. Yehuda, Z., and Saar, B. Derazne Estella, Sandler Vadim, Ianculovici Clariel, Halperin Tamar " Colonization of Candida: prevalence among tongue-pierced and non-pierced immunocompetent adults". Oral Dis, , 16(2), p-172-175(2010).

12. H.D.Chaudhari, Haresh R.Patel, and J.J.Vora "Catalytic and Biochemical study of novel Complexes of some Lanthanides". "International Journal of Research and Scientific Innovation” (IJRSI), 10(2) p-156-157(2015). 